\title{
Ultraviolet Vision May Enhance the Ability of Reindeer to Discriminate Plants in Snow
}

\author{
N.J.C. TYLER, ${ }^{1}$ G. JEFFERY, ${ }^{2}$ C.R. HOGG ${ }^{3}$ and K.-A. STOKKAN ${ }^{4}$
}

(Received 19 March 2013; accepted in revised form 22 August 2013)

\begin{abstract}
In reindeer/caribou (Rangifer tarandus), the lens and cornea of the eye transmit ultraviolet (UV) light, and the retinae respond to it electrophysiologically. Here we tie this finding to the unusual visual environment experienced by these animals and propose that their sensitivity to UV light enhances vision at the low luminance characteristic of the polar winter. For such visual enhancement to occur, it is essential that functional components of the environment, such as forage plants, be visually salient under natural UV luminance. It is not self-evident, however, that this is the case. Although organic material generally absorbs UV radiation, powerful scattering of UV light by snow crystals potentially reduces contrast with the background. We therefore recorded UV images of vegetation in situ on snow-covered pasture under natural winter (March) luminance in northern Norway. For each vegetation scene, we made three monochrome digital images at $350-390 \mathrm{~nm}$ (UV-Only), 400-750 nm (No-UV), and 350-750 nm (control), respectively. Plants at the snow surface appeared in high achromatic contrast against snow in UV-Only images. The contrast was substantially greater in the UV-Only images than in corresponding images in which UV was blocked. We conclude that plants are visually salient under natural UV luminance at wavelengths to which Rangifer are sensitive. This sensitivity is likely to improve the animals' ability to discriminate forage in snow, particularly at low but relatively UV-enriched twilight luminance.
\end{abstract}

Key words: albedo, caribou, Rangifer, reindeer, foraging, snow, ultraviolet, vascular plants, vision

RÉSUMÉ. Le cristallin et la cornée de l'œil du caribou (aussi connu sous le nom de renne) (Rangifer tarandus) transmettent une lumière ultraviolette (UV), à laquelle la rétine envoie une réponse électrophysiologique. Ici, nous faisons le lien entre cette observation et l'environnement visuel inhabituel de ces animaux, puis nous proposons que leur sensibilité à la lumière UV enrichit leur vision dans la faible luminance de l'hiver polaire. Pour que cet enrichissement ait lieu, il est essentiel que les composantes fonctionnelles de l'environnement, comme les plantes fourragères, soient visuellement saillantes sous la luminance UV naturelle. Il ne va cependant pas de soi que c'est le cas. Bien que la matière organique absorbe généralement le rayonnement ultraviolet, la diffusion puissante de la lumière UV découlant de la présence des cristaux de neige peut avoir pour effet de réduire le contraste avec l'arrière-plan. Par conséquent, nous avons enregistré des images ultraviolettes de la végétation in situ dans des pâturages couverts de neige sous la luminance naturelle de l'hiver (en mars), dans le nord de la Norvège. Pour chacune des scènes de végétation, nous avons fait trois images monochromes numériques, soit 350 à $390 \mathrm{~nm}$ (UV seulement), 400 à $750 \mathrm{~nm}$ (sans UV) et 350 à $750 \mathrm{~nm}$ (contrôlé), respectivement. Les plantes à la surface de la neige apparaissaient en fort contraste achromatique contre la neige dans le cas des images en UV seulement. Le contraste était beaucoup plus grand dans les images en UV seulement que dans les images correspondantes pour lesquelles l'UV était bloqué. Nous concluons que les plantes sont visuellement saillantes sous la luminance UV naturelle aux longueurs d'onde auxquelles le Rangifer est sensible. Cette sensibilité est susceptible d'améliorer l'aptitude de cet animal à distinguer le fourrage dans la neige, particulièrement en situation de faible luminance relativement enrichie en UV, au crépuscule.

Mots clés : albédo, caribou, Rangifer, renne, fourrage, neige, ultraviolet, plantes vasculaires, vision

Traduit pour la revue Arctic par Nicole Giguère.

\section{INTRODUCTION}

It has recently been demonstrated that in reindeer/caribou (Rangifer tarandus L., hereafter Rangifer) the lens and cornea of the eye transmit ultraviolet (UV) light, and the retinae respond to it electrophysiologically at $372 \mathrm{~nm}$ (Hogg et al., 2011) and at $333 \mathrm{~nm}$ (C.R. Hogg, unpubl. data). UV vision has been demonstrated in a variety of animals, including insects (e.g., Silberglied, 1979; Tovée, 1995; Chittka et al., 2013), birds (e.g., Carvalho et al., 2011;

\footnotetext{
${ }^{1}$ Corresponding author: Centre for Saami Studies, UiT The Arctic University of Norway, NO-9037 Tromsø, Norway; nicholas.tyler@uit.no

${ }^{2}$ Institute of Ophthalmology, University College London, 11-43 Bath Street, London EC1V 9EL, United Kingdom

${ }^{3}$ Moorfields Eye Hospital, 162 City Road, London EC1V 2PD, United Kingdom

${ }^{4}$ Department of Arctic and Marine Biology, UiT The Arctic University of Norway, NO-9037 Tromsø, Norway

(C) The Arctic Institute of North America
} 
Aidala et al., 2012), and non-primate mammals (Müller et al., 2009; Douglas and Jeffery, 2014), in which its specific function is not known (Hunt et al., 2001; Chavez et al., 2003; Honkavaara et al., 2008; Jacobs, 2009). Moreover, the only species of Cervidae examined (white-tailed deer Odocoileus virginianus $\mathrm{Z}$. and fallow deer Dama dama L.) were both found visually insensitive to very short wavelength UV (325 nm; Jacobs et al., 1994). These species are found in sub-temperate and temperate zones, whereas Rangifer is a boreal to super-boreal species complex. Hence, Hogg et al. (2011) and Stokkan et al. (2013) suggested that UV vision in Rangifer might be an adaptation to life at high latitudes. The polar light environment has extensive periods in winter in which the luminance is low, but the relative level of short wavelengths, including UV, is enhanced (Stamnes et al., 1988; Grenfell et al., 1994; Taulavuori et al., 2010). Rangifer are persistently active throughout these periods (van Oort et al., 2005, 2007), which raises the question of whether natural UV luminance might be functionally significant for the animals.

The visual environment at $70^{\circ} \mathrm{N}$ is predominantly mesopic to scotopic in winter. For five months, from midOctober to early April, light intensity does not exceed twilight for 12 to 24 hours per day, and twilight comprises 1290 hours (22\% of total time) compared to 430 hours (7\%) during the same period at $40^{\circ} \mathrm{N}$. Residual skylight radiation is UV-rich owing to the high level of atmospheric (Rayleigh) scattering of short wavelengths (Van de Hulst, 1957; Smith, 1982). At high latitudes, UV ground irradiance is predominantly diffuse (Stamnes et al., 1988) and may be greatly enhanced by the high albedo of snow (Wiscombe and Warren, 1980; Grenfell et al., 1994; Lenoble, 1998; Kylling et al., 2000). In addition, multiple scattering of UV between snow and clouds may moderate the attenuation of UV light through clouds (Nichol et al., 2003), especially where the cloud cover is broken (Weihs et al., 2000). In certain circumstances, UV irradiance under clouds may even exceed the cloudless value (Calbó et al., 2005; Wuttke and Seckmeyer, 2006).

We propose that the extension of the visual range of Rangifer into the UV potentially confers advantage by enhancing image formation at the low but relatively UVenriched levels of luminance characteristic of photic conditions during the polar winter. This proposal requires that biologically important elements of the environment be visually salient in situ under natural UV luminance. It is not self-evident, however, that this is the case. Plants, lichens, and soil strongly absorb UV light (e.g., Gausman et al., 1975; Robberecht et al., 1980; Petzold and Goward, 1988), and when viewed at wavelengths below $400 \mathrm{~nm}$, exposed swards will therefore normally form dark, low-contrast images that presumably contain reduced visual information. Snow entirely alters this situation, but not in a straightforward manner. On one hand, snow strongly reflects UV light, and plants, which absorb it, are therefore expected to show up in high contrast against the light (UV-reflecting) background. Where plants are closely surrounded by or even partially covered with snow, however, heterogeneous angular scattering of UV off randomly orientated snow crystals (Barkey et al., 2002; Kokhanovsky and Zege, 2004; Shcherbakov et al., 2006) potentially reduces this contrast. This possibility raises the question of how diminutive Arctic plants lying in the snow where Rangifer feed (Pruitt, 1959; LaPerriere and Lent, 1977; Skogland, 1978) appear under natural UV illumination. To address this question, we recorded UV (350-390 nm) and no UV (400-750 nm) images of vascular plants, a lichen, and a moss in situ in snow on Rangifer pasture under natural winter luminance.

\section{METHODS}

\section{Study Area}

Field observations were made on 2 March 2011 at a tree line site above boreal birch forest in the mountains of north-

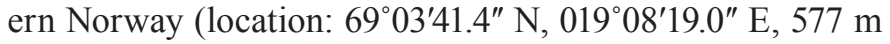
a.s.1.). The vegetation at this locality was dominated by Salix glauca shrubs in protected sites, Betula nana shrubs with Empetrum nigrum ssp. hermaphroditum in intermediate sites, and a few scattered small trees of Betula pubescens (Fig. 1a). Images were made of plants and lichen on the crown of a small windblown ridge and in the snow immediately surrounding it (Fig. 1a, b). In contrast with the general vicinity, where snow $(98 \%$ cover) was more than $30 \mathrm{~cm}$ deep, the experimental plot had snow depths of only 0 to $4 \mathrm{~cm}$ (Fig. 1b). The day of observation was heavily overcast with a strong wind, heavy snow flurries, and periodic whiteout. Ambient temperature was approximately $-1^{\circ} \mathrm{C}$. We revisited the plot on 12 August 2011 (Fig. 1a) to identify plants at the site.

\section{Imaging}

Vegetation was photographed in situ between 0900 and 1030 (GMT +2) in triplicate sets of monochrome digital images at 350-750 nm (No-filter), at 350-390 nm (UVOnly), and at $400-750 \mathrm{~nm}$ (No-UV), respectively, using two video cameras arranged on an acrylic mount so that their optical axes were parallel. Camera 1 (Sony VC34HQ-12) was a colour device fitted with a $25 \mathrm{~mm}$ f1.4 Cosmicar Pentax lens. Camera 2 (Watec WAT-902h Ultimate) was a high-sensitivity monochrome unit with a wide spectral sensitivity fitted with an uncoated $25 \mathrm{~mm}$ f1.9 Cosmicar lens (Part \# 44825). Camera 2 was tested with a series of visible and UV light-emitting diodes of specific wavelengths calibrated with a radiometer. The camera was sensitive through the visible spectrum and down to approximately $350 \mathrm{~nm}$ in the UV range (sensitivity at $370 \mathrm{~nm}=1.4 \cdot 10^{-6} \mathrm{~W} \cdot \mathrm{m}^{-2}$ ) and therefore spanned the range over which electrophysiological responses have been obtained in Rangifer (Hogg et al., 2011). Different spectral bands were isolated by restricting the light entering the camera with two filters arranged in series in a multi-position linear filter mount placed directly 


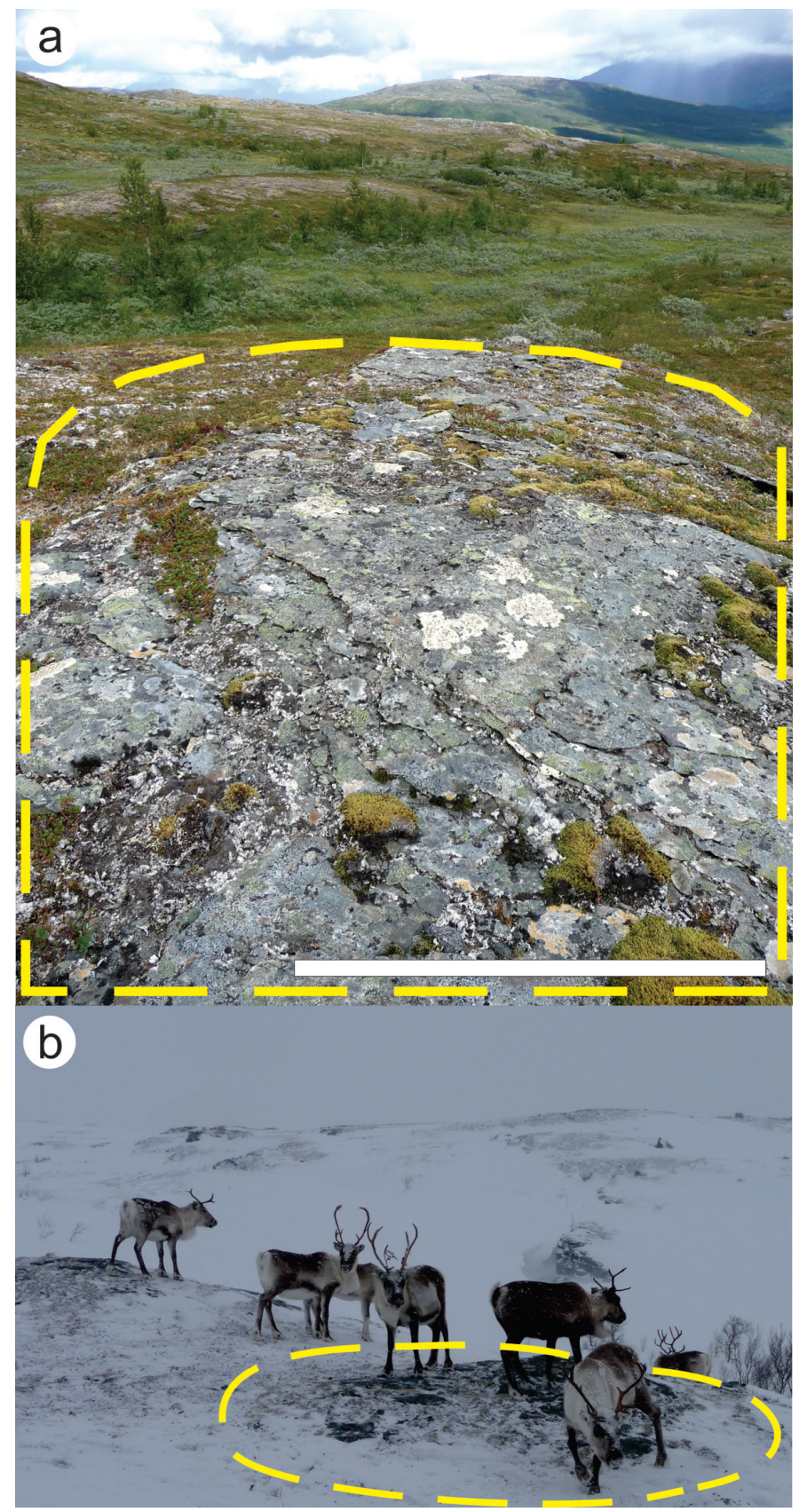

FIG. 1. Two views of the experimental site (yellow dashed line) at which vegetation scenes (vascular plants, lichen, moss) were photographed in situ under natural luminance. (a) 12 August 2011. (b) Day of observation (2 March 2011) with adult female reindeer. Scale bar: $1 \mathrm{~m}$.

in front of the lens. This filter arrangement provided three settings: full bandwidth (empty - No-filter - which served as a control), UV-Only (Hoya U-340), and full bandwidth less UV (No-UV, Schott GC395). A neutral density filter comprising two or four layers of Lee number 210 (0.6 log unit) ND filter, as necessary, was used to compensate for variation in input to the camera caused by the bandwidthlimiting filters. This filter has relatively uniform transmission from 400 to $690 \mathrm{~nm}(+4 \%$ to $-2 \%$ deviation from the nominal attenuation) but is slightly less uniform between 400 and $310 \mathrm{~nm}(+3 \%$ to $-10 \%$ deviation). However, increased attenuation in the latter range will have had negligible effect on the No-UV images, in which the UV was already heavily attenuated, and minimal effect on the fullbandwidth (control) images. Hence, given that the main comparison in our analysis was between No-UV and UVonly images, the effect was ignored. On the grounds that the images were sharp, we also discounted potential reduction in contrast of small elements in the images due to blurring caused by multiple filter layers. Images were recorded as BMP files on two portable computers via video to USB convertors (Climax digital - VCAP303) using Arcsoft One touch V3.0 frame capture software.

\section{Analysis of Data}

Three composite scenes of vegetation were selected for analysis. Each scene was represented by three monochrome images (No-filter, UV-Only, No-UV), which were cropped in Adobe Photoshop to the area of interest and until the area included in all three images of each set matched exactly. The level of contrast of images was assessed from the relative luminance of consecutive points along single straightline transects positioned identically over each image of a triplicate set for each scene (Fig. 2). Transects, unique to each scene, were placed subjectively to ensure that they crossed plants and substrate. The total number of points measured in each scene varied with both the length of the transect and the angular resolution, ranging from 313 points for moss to 407 for vascular plants. Each point consisted of one pixel crossed by the transect line. The relative luminance of each pixel was assessed using Matrox Inspector V2.1 and was scored on an arbitrary scale ranging from 0 (minimum/black) to 255 (maximum/white). Michelson contrast $(M)$ was then determined for each point (pixel) as:

$$
M=\left\{\frac{I_{\max }-I_{j}}{I_{\max }+I_{j}}\right\} \cdot 100 \%
$$

where $I_{j}$ was the luminance of the $j^{\text {th }}$ pixel in a given transect series and $I_{\max }$ was the maximum pixel value in that series. We plotted the resulting three series of $M$ values for each scene against transect position (point number) and compared the sets of paired values in the UV-Only and No-UV series using the Wilcoxon matched pairs signed ranks test (Siegel, 1956).

\section{RESULTS}

\section{Appearance}

Vascular plants, moss, and lichen appeared dark grey in UV-Only images, while snow appeared much lighter (Fig. 2d, i, n). Consequently, plants in or at the surface of the snow showed in high contrast against the background (snow), while plants or lichen on or near rock were not easily distinguished owing to low contrast with the substrate. 


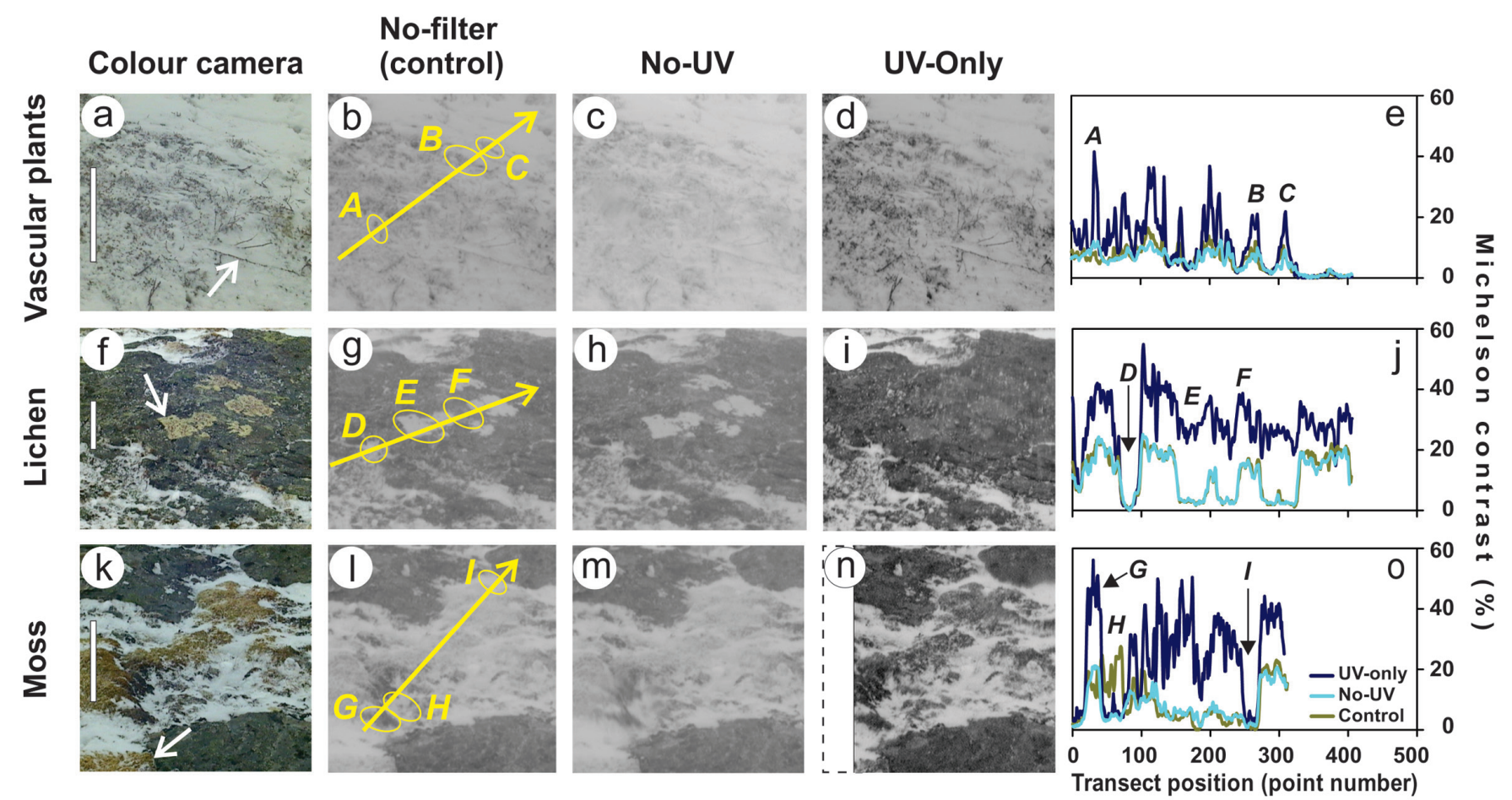

FIG. 2. Three composite scenes of vegetation in situ at the experimental site (Fig. 1). a-d: Mosaic of vascular plants in the snow. Species present include Betula nana $\times$ pubescens (white arrow in 'a'), Dryas octapetala, Empetrum nigrum, Festuca ovina, Vaccinium ulginosum, and $V$. vitis-idaea. $\mathrm{f}-\mathrm{i}$ : Patches of lichen Ophioparma ventosa (white arrow in ' $\mathrm{f}$ ') on a rock. $\mathrm{k}-\mathrm{n}$ : A patch of moss Racomitrium lanuginosum (light brown) between rocks. Each scene is presented in four ways: full chromatic range (a, f, k); monochrome 350-750 nm (No-filter (control); b, g, l); monochrome 400-750 nm (No-UV; c, h, m); and monochrome $350-390 \mathrm{~nm}$ (UV-Only; $\mathrm{d}, \mathrm{i}, \mathrm{n}$ ). Image $2 \mathrm{n}$ was corrupted at the left-hand border by water on the camera lens, and this part of the image (delineated by a dotted line) is therefore not shown. Relative luminance was measured at consecutive points (pixels) along transects placed identically over each monochrome image of a set (yellow arrows: shown only in b, g, and l). White arrow (in k) indicates a small patch of Racomitrium lanuginosum (see text). The graphs (e, $\mathrm{j}$, o) show the Michelson contrast of consecutive points along the transects in No-filter (control, dark yellow), No-UV (light blue), and UV-Only (dark blue) images of each scene. Transect point numbers (abscissae) run from the base to the tip of the transect arrows. Capital letters (A-I) in the graphs correspond with particular features within, but not delineated by, yellow rings (A-I) in the images. Note that there was virtually no difference in levels of contrast between the No-UV and No-filter (control) images for either the vascular plant or the lichen scene. Consequently, in graphs e and $\mathrm{j}$, the dark yellow (control) line lies beneath and is largely obscured by the light blue (No-UV) line. Scale bar: $25 \mathrm{~cm}$.

For instance, twigs of dwarf birch Betula nana (white arrow in Fig. 2a) and a large patch of moss Racomitrium lanuginosum (Fig. 2k) showed in high contrast against snow (Fig. 2d, n). But the greeny-yellow lichen Ophioparma ventosa (L.) Norman (= Haematomma ventosum (L.) Massal.), though conspicuous on a rock when observed in the full chromatic range (white arrow Fig. 2f), was almost invisible in the UV-Only image (Fig. 2i). Similarly, moss was clearly distinguishable from rock when observed in the full chromatic range (white arrow in Fig. 2k) but barely discernible in the UV-Only image (Fig. 2n).

\section{Contrast}

The Michelson contrast between pixels along the transects was consistently larger for UV-Only images than for the corresponding No-UV images in the three scenes $(p<0.0001$, Table 1$)$. Thus, matched transect points over organic material (and rock) were consistently darker (i.e., more strongly absorbent of UV) when viewed below $390 \mathrm{~nm}$, indicating that the plants and the species of lichen we observed absorbed more energy relative to the background (i.e., were less reflective) in the UV range than at longer (visible) wavelengths. This pattern was confirmed by examining specific regions along the transects. Thus, the Michelson contrast at point 'A' (Fig. 2b, e), where the transect crossed a Betula twig, was $41.5 \%$ in UV-Only, indicating lower reflectance (i.e., higher absorption) than in the No-UV image (11.4\%) and the No-filter (control) image $(7.6 \%)$. The close similarity of these latter values indicates little difference in reflectance of the twig between these images. Likewise, the Michelson contrast at a patch of lichen (point ' $E$ ' in Fig. $2 \mathrm{~g}$ ) was approximately $25 \%$ in the UV-Only image (Fig. 2j) compared with approximately 3\% in both the No-UV and No-filter (full bandwidth control) images, again indicating a lower reflectance of short (UV) wavelengths. Snow, which is highly reflective, represented a control, and as expected, the Michelson contrast at a patch of snow (point ' $\mathrm{D}$ ' in Fig. $2 \mathrm{~g}$ ) was less than $1 \%$ in all three images (Fig. 4j), indicating no difference in the reflectance of snow between any of these treatments. 
TABLE 1. Summary statistics of Michelson contrast (\%) of points along transects in matched sets of monochrome digital images for three vegetation scenes (vascular plants, lichen, and moss) photographed under natural luminance in situ on Rangifer pasture in winter. Light filters were used to produce three images of each scene: UV-Only (350-390 nm); No-UV (400-750 nm); and No-Filter (control, $350-750 \mathrm{~nm})$.

\begin{tabular}{|c|c|c|c|c|c|c|c|c|c|c|c|c|}
\hline & \multicolumn{4}{|c|}{ Vascular plants } & \multicolumn{4}{|c|}{ Lichen } & \multicolumn{4}{|c|}{ Moss } \\
\hline & UV-Only & No-UV & $z^{1}$ & $\begin{array}{l}\text { No-Filter } \\
\text { (control) }\end{array}$ & UV-Only & No-UV & $z^{1}$ & $\begin{array}{c}\text { No-Filter } \\
\text { (control) }\end{array}$ & UV-Only & No-UV & $z^{1}$ & $\begin{array}{l}\text { No-Filter } \\
\text { (control) }\end{array}$ \\
\hline Median & 9.2 & 5.7 & $-13.2 * * *$ & 6.0 & 28.0 & 12.8 & $-17.4 * * *$ & 12.9 & 23.1 & 5.2 & $-16.2 * * *$ & 6.1 \\
\hline maximum & 41.5 & 12.5 & & 16.4 & 54.9 & 25.2 & & 23.7 & 55.3 & 20.5 & & 27.6 \\
\hline minimum & 0 & 0 & & 0 & 0 & 0 & & 0 & 0 & 0 & & 0 \\
\hline$n$ & 407 & 407 & & 407 & 403 & 403 & & 403 & 313 & 313 & & 313 \\
\hline
\end{tabular}

${ }^{1} z=$ Comparison of UV-Only and No-UV; Wilcoxon matched-pairs signed rank test.

$* * *$ indicates $p$ (one-tailed) $<0.0001$.

\section{DISCUSSION}

Most plant material absorbs UV light, while snow strongly reflects it. In the absence of other considerations, therefore, plant material would be expected to stand out in relatively high contrast against snow when viewed with a visual system extending into the UV range. Our results confirm this expectation, and three elements of our experimental protocol, moreover, enhanced the interpretation of results in functional terms. First, we observed vascular plants and moss in situ, lying in or at the snow surface, where they were dusted with snow crystals. Second, we showed that both groups were visually salient at 350-390 nm, i.e., across the wavelengths at which UV sensitivity has been demonstrated in Rangifer (centred at $372 \mathrm{~nm}$; Hogg et al., 2011). Third, our demonstration was made under natural low luminance. The observation, under these circumstances, that plant material appeared in greater contrast against the snow background in UV-Only images, compared with images in which UV light was blocked, suggests that the UV element provides the animal with enhanced achromatic contrast. To our knowledge, this is the first time that UV vision in a mammal has been associated with the natural UV reflectance of biologically important elements of the environment observed in situ.

Notwithstanding various studies of retinal function (Hunt et al., 2001; Müller et al., 2009; Aidala et al., 2012) and animal responses to artificial UV illumination (e.g., Viitala et al., 1995; Church et al., 1998; Winter et al., 2003; Honkavaara et al., 2008), little is known about how natural UV illumination renders the world to mammals, including ruminants, with dichromatic vision (Tovée, 1995; Hunt et al., 2001, 2009; Bowmaker, 2008; Palacios et al., 2010). Application of band-pass filters in conjunction with a highsensitivity monochrome camera enabled us to create images within the spectral range of the UV visual capability of Rangifer. Vascular plants and moss appeared in high contrast against snow in the resulting UV-Only images (Fig. $2 \mathrm{~d}$ and $2 n$ ). The clarity of the images was remarkable bearing in mind that the plants were continually dusted with driven and falling snow as we worked. Scattering of UV off snow crystals on the plants and at the snow surface did not compromise image quality. The monochrome No-filter (Fig. 2b, g, 1) and No-UV images (Fig. 2c, h, m) appear pale and to be of lower contrast. Probably the reasons are (1) our being precluded from altering the internal setting of the camera (which would have invalidated comparison of the different forms of imaging) and (2) the greater spectral reflection off the plants (owing to the broader bandwidth compared with the UV-Only images). Expressing data in terms of the Michelson contrast circumvented these limitations and enabled us to make a legitimate comparison of the level of contrast in the different images.

Object discrimination depends on the visual acuity of the observer, the illumination at the relevant wavelengths, and the contrast of objects within the visual field (Endler, 1993). The enhanced contrast of our UV-Only images was by definition a consequence of an increased difference between the reflectance of plants and of snow below $390 \mathrm{~nm}$. A patch of lichen (strongly absorbent below $390 \mathrm{~nm}$ but reflecting in the visible part of the spectrum) on a rock (which has low reflectance across all wavelengths) was conspicuous when viewed in the full spectrum and No-UV images (Fig. 2f, h) but was virtually invisible in UV-Only (Fig. 2i). Whether contrast mediated by an extension of the visual range into the UV wavelengths is likely to be functionally significant in polar twilight (i.e., low luminance or scotopic conditions) depends on whether ambient UV light exceeds the sensitivity of Rangifer eyes, which is generally enhanced in winter (Stokkan et al., 2013; Tyler et al., 2014). The luminance level required for the scotopic threshold component of an electroretinogram response in Rangifer in winter $\left(5 \cdot 10^{-8} \mathrm{~W} \cdot \mathrm{m}^{-2}\right.$; Hogg et al., 2011) is approximately six orders of magnitude lower than the local ambient UV (350 to $400 \mathrm{~nm}$ ) incident on, and reflected from, snow measured at the time we recorded images of plants $\left(\simeq 6.5 \cdot 10^{-2}\right.$ $\mathrm{W} \cdot \mathrm{m}^{-2}$; C.R. Hogg, unpubl. data). These figures imply that both rods and cones of Rangifer would have been readily stimulated at 350 to $400 \mathrm{~nm}$ at this level of ambient light and that the animals may therefore have benefited from the enhanced contrast of plants and lichens at these wavelengths while searching for food in snow. 
There remains an obvious discrepancy between the UV wavelengths considered here $(350-390 \mathrm{~nm})$ and the peak sensitivity of the animals' photoreceptors, which is around $439 \mathrm{~nm}$ for the shorter wavelength cones and $510 \mathrm{~nm}$ for rods (Bowmaker, 2008; see also Hogg et al., 2011). Such receptors possess shoulders of sensitivity (around $150 \mathrm{~nm}$ either side of peak sensitivity) across which they will respond provided that stimuli are sufficiently strong. Enhanced contrast in the UV part of the spectrum is likely to be diluted by a lack of contrast at higher wavelengths. As a result, UV information is likely to have little functional significance for Rangifer in daylight, when their visual input is dominated by wavelengths greater than $400 \mathrm{~nm}$. We suggest, however, that the UV information is valuable at low luminance, i.e., before dawn, after sunset, and during the extended UV enriched twilight of the polar winter day.

\section{ACKNOWLEDGEMENTS}

We thank the Norwegian Army (Operation Support Troms/ Finnmark) for permission to enter the experimental site and for logistical support in the field; Yngve Sletten and Hannah and Ingfrid Tyler for assistance in the field; Torbjørn Alm and Arve Elvebakk for help with identification of plants; and four anonymous referees for criticism of earlier versions of the manuscript. This study was supported by a grant from the Biotechnology and Biological Sciences Research Council (UK).

\section{REFERENCES}

Aidala, Z., Huynen, L., Brennan, P.L.R., Musser, J., Fidler, A., Chong, N., Machovsky Capuska, G.E., et al. 2012. Ultraviolet visual sensitivity in three avian lineages: Paleognaths, parrots, and passerines. Journal of Comparative Physiology A 198(7):495-510.

http://dx.doi.org/10.1007/s00359-012-0724-3

Barkey, B., Bailey, M., Liou, K.-N., and Hallett, J. 2002. Lightscattering properties of plate and column ice crystals generated in a laboratory cold chamber. Applied Optics 41(27):5792-5796.

http://dx.doi.org/10.1364/AO.41.005792

Bowmaker, J.K. 2008. Evolution of vertebrate visual pigments. Vision Research 48(20):2022-2041. http://dx.doi.org/10.1016/j.visres.2008.03.025

Calbó, J., Pagès, D., and González, J.-A. 2005. Empirical studies of cloud effects on UV radiation: A review. Reviews of Geophysics 43, RG2002. http://dx.doi.org/10.1029/2004RG000155

Carvalho, L.S., Knott, B., Berg, M.L., Bennett, A.T.D., and Hunt, D.M. 2011. Ultraviolet-sensitive vision in longlived birds. Proceedings of the Royal Society (London) B 278(1702):107-114.

http://dx.doi.org/10.1098/rspb.2010.1100
Chavez, A.E., Bozinovic, F., Peichl, L., and Palacios, A.G. 2003. Retinal spectral sensitivity, fur coloration, and urine reflectance in the genus Octodon (Rodentia): Implications for visual ecology. Investigative Ophthalmology and Visual Science 44(5):2290-2296. http://dx.doi.org/10.1167/iovs.02-0670

Chittka, L., Stelzer, R.J., and Stanewsky, R. 2013. Daily changes in ultraviolet light levels can synchronize the circadian clock of bumblebees (Bombus terrestris). Chronobiology International 30(4):434-442.

http://dx.doi.org/10.3109/07420528.2012.741168

Church, S.C., Bennett, A.T.D., Cuthill, I.C., and Partridge, J.C. 1998. Ultraviolet cues affect the foraging behaviour of blue tits. Proceedings of the Royal Society (London) B 265(1405):1509-1514.

http://dx.doi.org/10.1098/rspb.1998.0465

Douglas, R.H., and Jeffery, G. 2014. The spectral transmission of ocular media suggests ultraviolet sensitivity is widespread among mammals. Proceedings of the Royal Society (London) B 281(1780). http://dx.doi.org/10.1098/rspb.2013.2995

Endler, J.A. 1993. The color of light in forests and its implications. Ecological Monographs 63(1):1-27. http://dx.doi.org/10.2307/2937121

Gausman, H.W., Rodriguez, R.R., and Escobar, D.E. 1975. Ultraviolet radiation reflectance, transmittance, and absorptance by plant leaf epidermises. Agronomy Journal 67(5):720-724. http://dx.doi.org/10.2134/agronj1975.00021962006700050036x

Grenfell, T.C., Warren, S.G., and Mullen, P.C. 1994. Reflection of solar radiation by the Antarctic snow surface at ultraviolet, visible, and near-infrared wavelengths. Journal of Geophysical Research 99(D9):18669-18684.

http://dx.doi.org/10.1029/94JD01484

Hogg, C., Neveu, M., Stokkan, K.-A., Folkow, L., Cottrill, P., Douglas, R., Hunt, D.M., and Jeffery, G. 2011. Arctic reindeer extend their visual range into the ultraviolet. Journal of Experimental Biology 214:2014-2019. http://dx.doi.org/10.1242/jeb.053553

Honkavaara, J., Åberg, H., and Viitala, J. 2008. Do house mice use UV cues when foraging? Journal of Ethology 26(3):339-345. http://dx.doi.org/10.1007/s10164-007-0068-6

Hunt, D.M., Wilkie, S.E., Bowmaker, J.K., and Poopalasundaram, S. 2001. Vision in the ultraviolet. Cellular and Molecular Life Sciences 58(11):1583-1598. http://dx.doi.org/10.1007/PL00000798

Hunt, D.M., Carvalho, L.S., Cowing, J.A., and Davies, W.L. 2009. Evolution and spectral tuning of visual pigments in birds and mammals. Philosophical Transactions of the Royal Society B 364(1531):2941-2955.

http://dx.doi.org/10.1098/rstb.2009.0044

Jacobs, G.H. 2009. Evolution of colour vision in mammals. Philosophical Transactions of the Royal Society B 364(1531):2957-2967. http://dx.doi.org/10.1098/rstb.2009.0039 
Jacobs, G.H., Deegan, J.F., II, Neitz, J., Murphy, B.P., Miller, K.V., and Marchinton, R.L. 1994. Electrophysiological measurements of spectral mechanisms in the retinas of two cervids: White-tailed deer (Odocoileus virginianus) and fallow deer (Dama dama). Journal of Comparative Physiology A 174:551-557. http://dx.doi.org/10.1007/BF00217375

Kokhanovsky, A.A., and Zege, E.P. 2004. Scattering optics of snow. Applied Optics 43(7):1589-1602. http://dx.doi.org/10.1364/AO.43.001589

Kylling, A., Dahlback, A., and Mayer, B. 2000. The effect of clouds and surface albedo on UV irradiances at a high latitude site. Geophysical Research Letters 27(9):1411-1414. http://dx.doi.org/10.1029/1999GL011015

LaPerriere, A.J., and Lent, P.C. 1977. Caribou feeding sites in relation to snow characteristics in northeastern Alaska. Arctic 30(2):101-108. http://dx.doi.org/10.14430/arctic2690

Lenoble, J. 1998. Modeling of the influence of snow reflectance on ultraviolet irradiance for cloudless sky. Applied Optics 37(12):2441-2447. http://dx.doi.org/10.1364/AO.37.002441

Müller, B., Glösmann, M., Peichl, L., Knop, G.C., Hagemann, C., and Ammermüller, J. 2009. Bat eyes have ultraviolet-sensitive cone photoreceptors. PLoS ONE 4: e6390. http://dx.doi.org/10.1371/journal.pone.0006390

Nichol, S.E., Pfister, G., Bodeker, G.E., McKenzie, R.L., Wood, S.W., and Bernhard, G. 2003. Moderation of cloud reduction of UV in the Antarctic due to high surface albedo. Journal of Applied Meteorology 42:1174-1183.

http://dx.doi.org/10.1175/1520-0450(2003)042<1174:MOCROU $>2.0 . \mathrm{CO} ; 2$

Palacios, A.G., Bozinovic, F., Vielma, A., Arrese, C.A., Hunt, D.M., and Peichl, L. 2010. Retinal photoreceptor arrangement, SWS1 and LWS opsin sequence, and electroretinography in the South American marsupial Thylamys elegans (Waterhouse, 1839). The Journal of Comparative Neurology 518(9):1589- 1602. http://dx.doi.org/10.1002/cne.22292

Petzold, D.E., and Goward, S.N. 1988. Reflectance spectra of subarctic lichens. Remote Sensing of Environment 24(3):481-492. http://dx.doi.org/10.1016/0034-4257(88)90020-X

Pruitt, W.O., Jr. 1959. Snow as a factor in the winter ecology of the barren ground caribou (Rangifer arcticus). Arctic 12(3):158-179. http://dx.doi.org/10.14430/arctic3723

Robberecht, R., Caldwell, M.M., and Billings, W.D. 1980. Leaf ultraviolet optical properties along a latitudinal gradient in the Arctic-Alpine life zone. Ecology 61(3):612-619. http://dx.doi.org/10.2307/1937427

Shcherbakov, V., Gayet, J.-F., Baker, B., and Lawson, P. 2006. Light scattering by single natural ice crystals. Journal of the Atmospheric Sciences 63(5):1513-1525. http://dx.doi.org/10.1175/JAS3690.1

Siegel, S. 1956. Non-parametric statistics for the behavioural sciences. New York: McGraw-Hill.
Silberglied, R.E. 1979. Communication in the ultraviolet. Annual Review of Ecology and Systematics 10:373-398. http://dx.doi.org/10.1146/annurev.es.10.110179.002105

Skogland, T. 1978. Characteristics of the snow cover and its relationship to wild mountain reindeer (Rangifer tarandus tarandus L.) feeding strategies. Arctic and Alpine Research 10(3):569-579. http://dx.doi.org/10.2307/1550680

Smith, H. 1982. Light quality, photoperception, and plant strategy. Annual Review of Plant Physiology 33:481-518. http://dx.doi.org/10.1146/annurev.pp.33.060182.002405

Stamnes, K., Henriksen, K., and Østensen, P. 1988. Simultaneous measurement of UV radiation received by the biosphere and total ozone amount. Geophysical Research Letters 15(8):784-787. http://dx.doi.org/10.1029/GL015i008p00784

Stokkan, K.-A., Folkow, L., Dukes, J., Neveu, M., Hogg, C., Siefken, S., Dakin, S.C., and Jeffery, G. 2013. Shifting mirrors: Adaptive changes in retinal reflections to winter darkness in Arctic reindeer. Proceedings of the Royal Society (London) B 280(1773).

http://dx.doi.org/10.1098/rspb.2013.2451

Taulavuori, K., Sarala, M., and Taulavuori, E. 2010. Growth responses of trees to Arctic light environment. In: Lüttge, U., Beyschlag, W., Büdel, B., and Francis, D., eds. Progress in Botany 71. Berlin and Heidelberg: Springer-Verlag. 157-168. http://dx.doi.org/10.1007/978-3-642-02167-1_6

Tovée, M.J. 1995. Ultra-violet photoreceptors in the animal kingdom: Their distribution and function. Trends in Ecology \& Evolution 10(11):455-460. http://dx.doi.org/10.1016/S0169-5347(00)89179-X

Tyler, N., Stokkan, K.-A., Hogg, C., Nellemann, C., Vistnes, A.I., and Jeffery, G. 2014. Ultraviolet vision and avoidance of power lines in birds and mammals. Conservation Biology. http://dx.doi.org/10.1111/cobi.12262

Van de Hulst, H.C. 1957. Light scattering by small particles. New York: Dover Publications Inc.

Van Oort, B.E.H., Tyler, N.J.C., Gerkema, M.P., Folkow, L., Blix, A.S., and Stokkan, K.-A. 2005. Circadian organization in reindeer. Nature 438(7071):1095-1096. http://dx.doi.org/10.1038/4381095a

Van Oort, B.E.H., Tyler, N.J.C., Gerkema, M.P., Folkow, L., and Stokkan, K.-A. 2007. Where clocks are redundant: Weak circadian mechanisms in reindeer living under polar photic conditions. Naturwissenschaften 94(3):183-194. http://dx.doi.org/10.1007/s00114-006-0174-2

Viitala, J., Korpimäki, E., Palokangas, P., and Kolvula, M. 1995. Attraction of kestrels to vole scent marks visible in ultraviolet light. Nature 373(6513):425-427. http://dx.doi.org/10.1038/373425a0

Weihs, P., Webb, A.R., Hutchinson, S.J., and Middleton, G.W. 2000. Measurements of the diffuse UV sky radiance during broken cloud conditions. Journal of Geophysical Research 105 (D4):4937-4944. http://dx.doi.org/10.1029/1999JD900260 
Winter, Y., López, J., and von Helversen, O. 2003. Ultraviolet vision in a bat. Nature 425(6958):612-614. http://dx.doi.org/10.1038/nature01971

Wiscombe, W.J., and Warren, S.G. 1980. A model for the spectral albedo of snow. I: Pure snow. Journal of the Atmospheric Sciences 37(12):2712-2733.

http://dx.doi.org/10.1175/1520-0469(1980)037<2712:AMFTSA $>2.0 . \mathrm{CO} ; 2$
Wuttke, S., and Seckmeyer, G. 2006. Spectral radiance and sky luminance in Antarctica: A case study. Theoretical and Applied Climatology 85(3-4):131-148. http://dx.doi.org/10.1007/s00704-005-0188-2 